\title{
THE EFFICIENCY OF PRODUCTION FACTORS ON AGRICULTURAL FARMS OF THE VISEGRAD GROUP
}

The objective of the study was to determine the effectiveness of the use of production factors on farms of the Visegrad Group countries. The research covered farms participating in the European system for collecting accounting data from FADN (Farm Accountancy Data Network) farms. Under the main objective, an assessment was made of the productivity and profitability of land, labour and capital. The research period covered the years 2014-2017.

Based on the analyses that was conducted, it was found that the most effective use of land resources was on farms in Hungary and Poland, and the least effective in Slovakia. Considering labour and capital productivity, the highest results were achieved by farms in the Czech Republic and Slovakia, while the lowest by Polish farms. On the other hand, Hungarian farms were characterized by the highest profitability of labour and return on assets, where the analysed indicators were higher than the EU average.

Key words: effectiveness, agricultural farms, FADN, Visegrad Group JEL Codes: Q12, Q14

\section{Introduction}

The Visegrad Group (V4) is an example of cooperation between four countries in Central and Eastern Europe. It was founded in 1991 by a declaration signed in the city of Visegrad by the leaders of three countries: Poland, Czechoslovakia and Hungary. After the collapse of Czechoslovakia, both the Czech Republic and Slovakia became members of the group. The original goal of the V4 group was to strengthen cooperation and mutual support in activities aimed at joining the European Union and NATO. The 28-year cooperation within the Visegrad Group has developed a wide scope and covers many fields, including foreign policy, security and defence, transportation and infrastructure, economy, agriculture, regional development, education, culture and tourism. Although the V4 countries have similar historical experience, geographical location and similar goals in foreign policy, they are characterized by different models of agriculture and rural development, which result from their specific conditions and agricultural structures. In connection with the above, the study of socio-economic processes occurring in agriculture in the Visegrad Group countries, and evaluation of the efficiency of their agricultural farms, is gaining in significance, especially after accession to the European Union in $2004^{1}$.

\footnotetext{
${ }^{1}$ A. Piwowar: Struktury rolne i produktywność rolnictwa w Grupie Wyszehradzkiej. Problems of World Agriculture 17/2017, s. 152-160.
} 
It is worth noting that while the literature on the subject includes studies on the economic situation of agricultural farms and development trends in agriculture in Poland and other European Union countries, relatively few analyze the efficiency of farms of the Visegrad Group countries ${ }^{2}$.

Efficiency is used to describe the functioning and assessment of the development opportunities of an organization. It is the subject of consideration in various aspects of activities, but it is not clearly defined. Most often, in economic theory, efficiency is defined as the ratio of the effects obtained to the expenditure incurred ${ }^{3}$. The effect can be production, income, profit - and expenditure can be costs and resources involved: land, labour and capital. Efficiency is associated with such concepts as competence, effectiveness of undertaken actions, profitability, productivity and purposefulness ${ }^{4}$. The literature also describes the efficiency of management, which refers to the assessment of the rationality of actions in solving problems of allocation of limited resources between alternative applications ${ }^{5}$.

The basic economic category used to assess agricultural farms is economic efficiency, which means achieving given results at the lowest possible expenditure ${ }^{6}$. In other words, economic efficiency is the result of rational management, which is a relation of the achieved effects to the expenditure incurred ${ }^{7}$. The efficiency with expenditures are transformed into effects is also one of the conditions for creating general economic equilibrium on agricultural farms ${ }^{8}$. Analysing the effectiveness of the use of resources held by means of productivity and profitability indicators, it is possible to assess the efficiency of farming ${ }^{9}$.

Agricultural production efficiency is generally measured by taking into account three main production factor resources, i.e. land, labour and capital. These elements largely determine the development possibilities of agriculture ${ }^{10}$. Land is one of the basic factors of production in agriculture, and its efficient use determines the state

\footnotetext{
2 A. Piwowar: Struktury rolne i produktywność rolnictwa w Grupie Wyszehradzkiej. Problems of World Agriculture 17/2017, s. 152-160; L. Szabo, M. Grznar, M. Zelina: Agricultural performance in the V4 countries and its position in the European Union. Agricultural Economics, 64(8)/2018, p. 337-346.

${ }^{3}$ P.J. Barry, C.B. Baker, P.N. Ellinger, J.A. Hopkin: Financial Management in Agriculture. Interstate Publisher, Illinis 1995.

4 A. Masternak-Janus: Analiza efektywności gospodarowania przedsiębiorstw przemysłowych w Polsce. Economics and Management, 4/2013, s. s. 111-126.

${ }^{5}$ M. Wasilewski, A. Wasilewska: Koszty i efektywność pracy w przedsiębiorstwach rolniczych. Roczniki Nauk Rolniczych, Seria G, 94(1)/2007, s. 86-94.

${ }^{6}$ E. Szymańska: Efektywność przedsiębiorstw- definiowanie i pomiar. Roczniki Nauk Rolniczych, SERIA G 97(2)/2010, s. 152-164.

${ }^{7}$ A. Masternak-Janus: Analiza efektywności gospodarowania przedsiębiorstw przemysłowych w Polsce. Economics and Management, 4/2013, s. s. 111-126; W. Ziętara, M. Zieliński: Efektywność i konkurencyjność polskich gospodarstw rolniczych nastawionych na produkcję roślinną. Zagadnienia Ekonomiki Rolnej, 1/2012, s. 40-61.

${ }^{8}$ K. Niewiadomski: Efektywność ekonomiczna gospodarstw rolniczych. Zagadnienia Ekonomiki Rolnej, 3/2007, s. 81-92.

9 R. Manteufel: Ekonomika i organizacja gospodarstwa rolniczego. PWRiL, Warszawa 1979; J.S. Zegar: Dochody rolników po akcesji w Unii Europejskiej. Raport „Realia i co dalej” 4/2011, s. 9-35; M.J. Orłowska: Zasoby czynników produkcji oraz ich efektywność w gospodarstwach o różnej wielkości ekonomicznej w świetle FADN. Roczniki Naukowe Stowarzyszenia Ekonomistów Rolnictwa i Agrobiznesu, 17(2)/2015, s. 189-195.

10 W. Poczta: Rolnictwo polskie w przededniu integracji z Unią Europejską. Wydawnictwo Akademii Rolniczej w Poznaniu, Poznań 2003.
} 
of development of individual farms more than the area of arable land or the level of production ${ }^{11}$. Relating production results appropriately enables the assessment of production efficiency, just as evaluating economic results helps determine economic efficiency.

Research shows that diversification in the efficiency of using basic production factors on agricultural farms is influenced, among others, by agricultural type ${ }^{12}$, economic size of the farm ${ }^{13}$, natural and climatic conditions, as well as historical and legal conditions ${ }^{14}$.

The objective of the study was to determine the effectiveness of the use of production factors (land, labour and capital) on agricultural farms in the Visegrad Group countries. Within the main objective, an assessment was made of the productivity and profitability of land, labour and capital.

\section{Research material and methodology}

The selection of farms for research was intentional. These were farms of the Visegrad Group, participating in the European system of collecting accounting data from FADN (Farm Accountancy Data Network) farms. The FADN field of observation includes commercial farms that produce about $90 \%$ of the value of Standard Production in a given region or a country. In 2017, agricultural farms from the V4 group constituted $18.5 \%$ of the European FADN, of which the most numerous were Polish farms and the least numerous were Slovak farms (Table 1).

Table 1. The size of the FADN sample in individual countries of the Visegrad Group in 2017

\begin{tabular}{|c|r|r|r|r|r|r|}
\hline Country & Poland & Hungary & \multicolumn{1}{c|}{$\begin{array}{c}\text { Czech } \\
\text { Republic }\end{array}$} & Slovakia & V4 group & EU \\
\hline $\begin{array}{c}\text { Number of } \\
\text { farms }\end{array}$ & 12100 & 1900 & 1417 & 562 & 15974 & 86255 \\
\hline $\begin{array}{c}\text { Participation in } \\
\text { FADN }(\%)\end{array}$ & 14,0 & 2,2 & 1,6 & 0,7 & 18,5 & 100 \\
\hline
\end{tabular}

Source: authors' own study based on Polish FADN data.

\footnotetext{
${ }^{11}$ J. Bud-Gusaim: Efektywność zasobów produkcyjnych w rolnictwie indywidualnym Polski. PWN, Warszawa 1988.

${ }^{12}$ A. Marcysiak: Efektywność wykorzystania zasobów produkcyjnych w różnych typach gospodarstw jako element oceny ich siły konkurencyjnej. Roczniki Naukowe SERIA, X(3)/2008, s. 380-385; D. Komorowska: Typ rolniczy a efektywność gospodarstw ekologicznych. Roczniki Naukowe Rolnictwa i Rozwoju Obszarów Wiejskich, 99(4)/2012, s. 105-120; A. Gałecka: Typ rolniczy a efektywność gospodarstw rolniczych w Polsce. Zarządzanie Finansami i Rachunkowość, 5(2)/2017, s. 17-27; T. Filipiak: Efficiency of production factors in horticultural holdings versus holdings of other agricultural types. Annals of the Polish Association of Agricultural and Agrobusiness Economists, 21(4)/2019, p. 126-135.

${ }_{13}$ W. Poczta, J. Średzińska: Wyniki produkcyjno-ekonomiczne i finansowe indywidualnych gospodarstw rolnych według ich wielkości ekonomicznej (na przykładzie regionu FADN Wielkopolska i Śląsk). Zeszyty Naukowe Szkoły Głównej Gospodarstwa Wiejskiego w Warszawie. Problemy Rolnictwa Światowego, 2/2007, s. 433-443; P. Bórawski: Wielkość ekonomiczna jako czynnik różnicujący wyniki produkcyjne i ekonomiczne gospodarstw rolnych w regionie Pomorze i Mazury. Zeszyty Naukowe SGGW w Warszawie. Ekonomika I Organizacja Gospodarki Żywnościowej, 67/2008, s. 45-55; A. Gałecka: Efektywność gospodarstw rolnych w Polsce w latach 2012-2015 w zależności od ich wielkości ekonomicznej. Roczniki Naukowe SERiA, 19(5)/2017, s. 65-71.

${ }^{14}$ A. Piwowar: Struktury rolne i produktywność rolnictwa w Grupie Wyszehradzkiej. Problems of World Agriculture 17/2017, s. 152-160; L. Szabo, M. Grznar, M. Zelina: Agricultural performance in the V4 countries and its position in the European Union. Agricultural Economics, 64(8)/2018, p. 337-346.
} 
The subject of the study was economic efficiency understood as the ratio of obtained effects to incurred expenditure. Agricultural production and farm income were assumed as effects, while the resources of land, labour and capital involved were assumed as expenditure. To assess the efficiency of agricultural farms, land productivity indicators, asset productivity, economic labour efficiency, land profitability, own labour profitability, and asset profitability were used. These were targeted, commonly used measures of economic efficiency, based on both the production category (productivity indicators) and farm income (profitability indicators). The research period covered the years 2014-2017. The basic sources of information were Eurostat data and literature on the subject.

\section{Results and discussion}

Table 2 presents production resources of farms in the Visegrad Group countries in 2014-2017. It was found that the researched farms were diversified in terms of utilized average agricultural area (UAA) from 18 ha in Poland to over 500 ha in Slovakia. In Slovakia and the Czech Republic, large-scale farms dominate, the area of which even several times exceeds the average in the European Union. However, the most fragmented agrarian structure is observed in Poland. In the analysed period, a growing trend was recorded in the UAA in Poland and the Czech Republic, which was in line with the trend in the EU. In the other two countries of the V4 group a decrease in UAA was found.

Table 2. Resources of agricultural farm production factors in the Visegrad countries in 2014-2017

\begin{tabular}{|c|c|c|c|c|c|}
\hline \multirow{2}{*}{ Years } & \multicolumn{5}{|c|}{ Country } \\
\hline & Poland & Hungary & Czech Republic & Slovakia & EU average \\
\hline \multicolumn{6}{|c|}{ Total UAA (ha) } \\
\hline 2014 & 18,4 & 49,2 & 201,8 & 532,0 & 33,9 \\
\hline 2015 & 18,5 & 49,9 & 203,9 & 528,6 & 34,0 \\
\hline 2016 & 18,8 & 47,9 & 204,6 & 525,3 & 34,3 \\
\hline 2017 & 19,0 & 47,0 & 205,8 & 500,7 & 34,9 \\
\hline Change 2017-2014 & 0,6 & $-2,2$ & 4,0 & $-31,3$ & 1,0 \\
\hline \multicolumn{6}{|c|}{ Total labour input (AWU) } \\
\hline 2014 & 1,7 & 1,6 & 5,6 & 12,4 & 1,6 \\
\hline 2015 & 1,6 & 1,6 & 5,6 & 12,4 & 1,5 \\
\hline 2016 & 1,6 & 1,6 & 5,6 & 12,3 & 1,5 \\
\hline 2017 & 1,6 & 1,6 & 5,4 & 12,1 & 1,5 \\
\hline Change 2017-2014 & $-0,1$ & 0,0 & $-0,2$ & $-0,3$ & $-0,1$ \\
\hline \multicolumn{6}{|c|}{ Total assets per 1 ha UAA (EUR/ha) } \\
\hline 2014 & 9143 & 3637 & 3091 & 2110 & 9674 \\
\hline 2015 & 9206 & 3686 & 3284 & 2185 & 9946 \\
\hline 2016 & 8891 & 4201 & 3406 & 2273 & 9966 \\
\hline 2017 & 9402 & 4391 & 3639 & 2411 & 10132 \\
\hline Change 2017-2014 & 259 & 754 & 548 & 301 & 458 \\
\hline
\end{tabular}

Source: authors' own study based on Eurostat data.

The highest average number of full-time employees (in $\mathrm{AWU}^{15}$ ) was on farms in Slovakia and amounted to 12 people, while the lowest was in Poland - fewer than 2 people. In 2017, compared to 2014, there was a decrease in total labour input among V4

15 AWU - total labour input of holding expressed in annual work units = full-time person equivalents $(1$ AWU=2120 working hours in total per year) 
group countries, which was the result of greater mechanization of production, mainly on very large and specialized farms.

Analysing the capital resources of agricultural farms, it was found that the largest value of total assets (fixed and current assets) per 1 ha of utilized agricultural area was characteristic for Polish and Hungarian farms, respectively about 9,000 EUR /1 ha of UAA and about 4, 000 EUR /1ha of UAA. Farms in the Czech Republic recorded a slightly lower level, while in Slovakia there were just over 2,000 EUR/1 ha of UAA. In all countries of the Group an increase in the value of total assets was noted, which resulted, among others, from the increase in land value in the analysed period.

Chart 1 presents the average value of total production achieved by farms in the studied region. The highest level of production was recorded in farms in Slovakia, i.e. those with the largest UAA, and the lowest in Poland, which have a fragmented agrarian structure. It can therefore be concluded that there is a positive relationship between farm income and UAA.

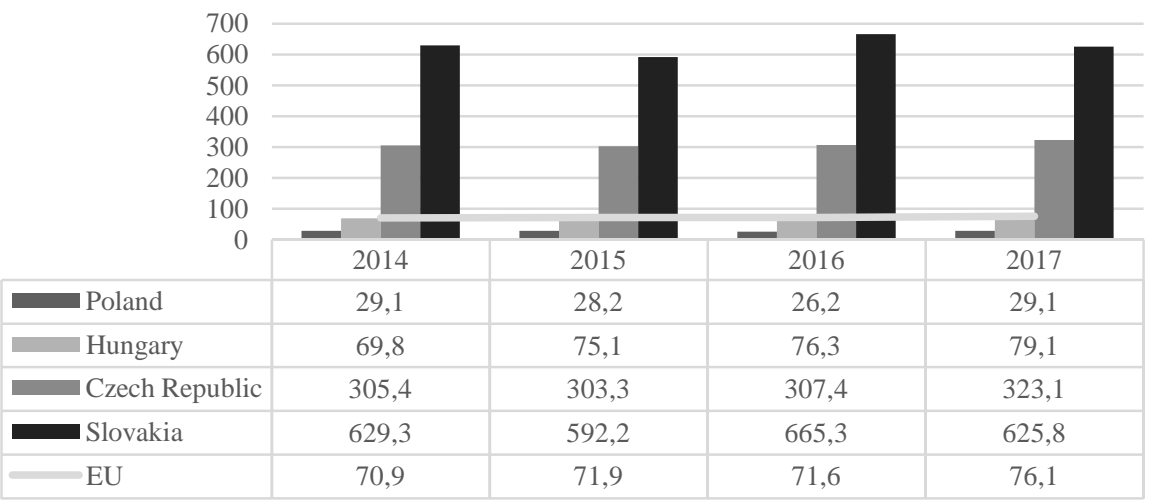

Chart 1. Average total output of agricultural farms in the Visegrad countries in 2014-2017 (thous. EUR) Source: authors' own work based on Eurostat data.

Table 3 presents the land, labour and capital productivity of the surveyed farms measured by the value of agricultural production per 1 ha of UAA (land productivity), per unit of AWU work (labour productivity) and per 100 EUR of total assets (capital productivity). According to the analysis, in 2014-2017 the productivity of land (except Poland) and labour in V4 countries increased, which is a positive trend. The highest land productivity among the Group countries in 2017 was recorded in Hungary (1683 EUR/ha) and in the Czech Republic (1570 EUR/ha), while the lowest was in Slovakia (1250 EUR/ha). In comparison, the average production value per 1 ha of UAA in EU countries in this period was $2183 \mathrm{EUR} / \mathrm{ha}$, which means that in the studied group the efficiency of using land resources is much lower. It should be noted that the productivity of land depends not only on the size of arable land but also on the way it is developed and the use of labour and capital resources. 
Table 3. Productivity of land, labour and capital of agricultural farms in the Visegrad countries in 2014-2017 (average per holding)

\begin{tabular}{|c|c|c|c|c|c|}
\hline \multirow[b]{2}{*}{ Years } & \multicolumn{5}{|c|}{ Country } \\
\hline & Poland & Hungary & $\begin{array}{c}\text { Czech } \\
\text { Republic }\end{array}$ & Slovakia & EU average \\
\hline \multicolumn{6}{|c|}{ Land productivity (EUR/ha UAA) } \\
\hline 2014 & 1582,7 & 1418,0 & 1513,6 & 1182,8 & 2094,8 \\
\hline 2015 & 1527,5 & 1504,9 & 1487,1 & 1120,3 & 2112,8 \\
\hline 2016 & 1397,6 & 1592,8 & 1502,3 & 1266,4 & 2089,5 \\
\hline 2017 & 1535,3 & 1682,7 & 1570,4 & 1249,9 & 2182,9 \\
\hline Change 2017-2014 & $-47,4$ & 264,7 & 56,8 & 67,1 & 88,1 \\
\hline \multicolumn{6}{|c|}{ Labour productivity (EUR/AWU) } \\
\hline 2014 & 17438,3 & 43084,0 & 54824,8 & 50626,5 & 45467,3 \\
\hline 2015 & 17193,9 & 46382,1 & 54059,5 & 47602,3 & 47007,2 \\
\hline 2016 & 16101,8 & 48624,8 & 54897,1 & 54307,2 & 47723,3 \\
\hline 2017 & 18183,8 & 50406,4 & 59510,9 & 51551,4 & 50395,4 \\
\hline Change 2017-2014 & 745,5 & 7322,4 & 4686,1 & 924,9 & 4928,1 \\
\hline \multicolumn{6}{|c|}{ Capital productivity (EUR) } \\
\hline 2014 & 17,3 & 39,0 & 49,0 & 56,1 & 21,7 \\
\hline 2015 & 16,6 & 40,8 & 45,3 & 51,3 & 21,2 \\
\hline 2016 & 15,7 & 37,9 & 44,1 & 55,7 & 21,0 \\
\hline 2017 & 16,3 & 38,3 & 43,2 & 51,9 & 21,5 \\
\hline Change 2017-2014 & $-1,0$ & $-0,7$ & $-5,8$ & $-4,2$ & $-0,2$ \\
\hline
\end{tabular}

Source: authors' own work based on Eurostat data.

In terms of labour productivity measured as total production per employee, V4 countries can be divided into 2 groups. The Czech Republic and Slovakia reached over 50,000 EUR, Hungary a little less (from 43,000 EUR in 2014 to 50,000 EUR in 2017). The worst in this respect was Poland, where this indicator was more than twice lower compared to other countries in the Group, as well as in relation to the EU average. In 2017, compared to 2014, all countries of the Visegrad Group recorded an increase in labour productivity (from $2 \%$ in Slovakia to $17 \%$ in Hungary), which is a positive trend.

The highest capital productivity in the analysed period was recorded in agricultural farms in Slovakia (an annual average over 50 EUR of production value per 100 EUR total assets), where the value of assets was the lowest, while the value of production was the highest. It can therefore be concluded that these farms rationally matched the level and structure of assets to the possibilities of its effective use. Agricultural farms in Poland achieved a more than twice lower indicator, which was the lowest efficiency in the Group. It should be noted that the surveyed farms from V4 countries (with the exception of Polish farms) were characterized by higher capital productivity compared to the EU average, although in 2017 compared to 2014 a decrease in this indicator was noted.

The effectiveness of the use of production factors can also be assessed by taking as an effect not the value of production but farm income, which according to the FADN methodology is calculated by adding to the net added value the balance of subsidies and taxes related to investments and deducting the cost of external factors. The development of income on the surveyed farms is illustrated in Chart 2. 


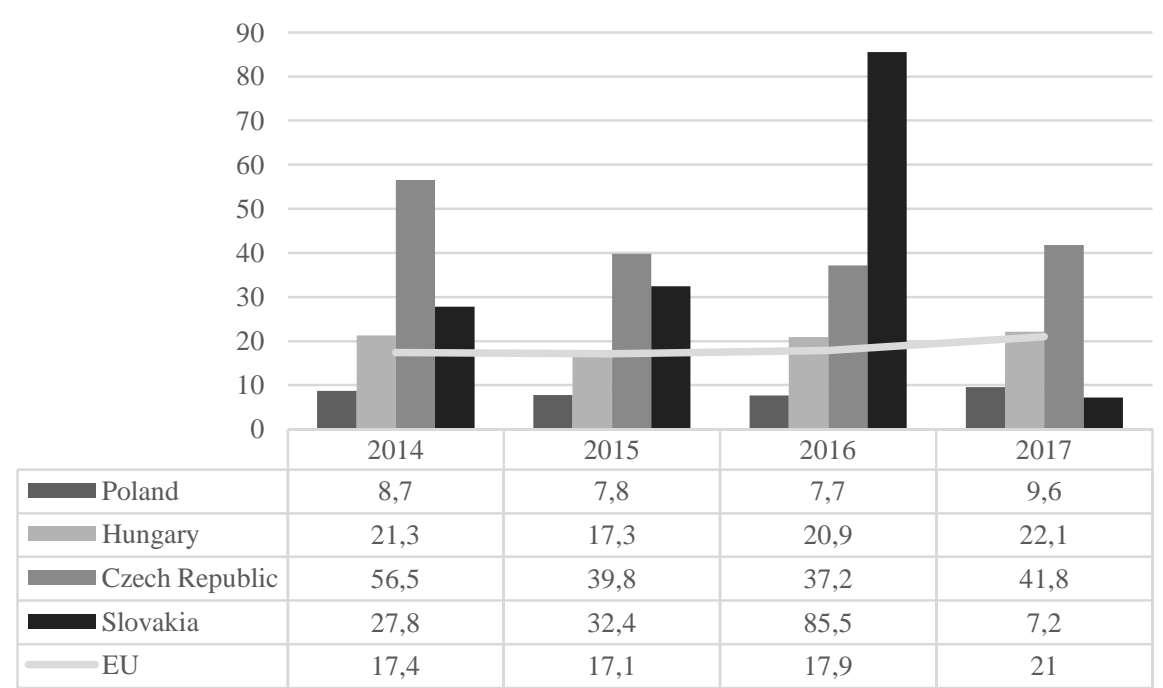

Chart 2. Average income of agricultural farms in the Visegrad countries in 2014-2017 (thous. EUR) Source: authors' own work based on Eurostat data.

In the years 2014-2017, the highest level of income was recorded in the Czech Republic, with the exception of 2016 when farms in Slovakia achieved higher income it amounted to over 85,000 EUR, which is almost 5 times more than the EU average. In the analysed period, the lowest average income (more than twice lower than the EU average) was characteristic for agricultural farms in Poland, from 7,700 EUR up to 9,600 EUR. In 2017, compared to 2014, an increase in the value of agricultural income was recorded in Poland and Hungary, while in the Czech Republic and Slovakia a decrease, which was related to the economic situation on the agricultural market in individual regions.

Table 4 presents the results of the agricultural farm profitability analysis in the Visegrad countries. In the analysed period, the highest value of agricultural farm income per 1 ha of UAA was found in Poland (from 411 EUR in 2016 to 508 EUR in 2017). Hungarian agricultural farms reported very similar profitability of land. The agricultural farms of the Czech Republic achieved twice lower efficiency of land use, while the lowest income per 1 ha of UAA was found in Slovakia, where in 2017 the analysed indicator was 35 times lower compared to Poland and over 40 times lower than the EU average. There was an inverse relationship between the average UAA and land profitability, which resulted from relatively low income per 1 ha on large-scale farms. The efficiency of using farm land resources from V4 countries was below the EU average. In 2017, compared to 2014, there was an increase in land profitability in Poland and Hungary, while there was a decrease in the Czech Republic and Slovakia, which resulted from changes in income of farms. 
Table 4. Profitability of land, labour and capital of agricultural farms in the Visegrad countries in 2014-2017

\begin{tabular}{|c|c|c|c|c|c|}
\hline \multirow[b]{2}{*}{ Years } & \multicolumn{5}{|c|}{ Country } \\
\hline & Poland & Hungary & $\begin{array}{c}\text { Czech } \\
\text { Republic }\end{array}$ & Slovakia & EU average \\
\hline \multicolumn{6}{|c|}{ Profitability of land (EUR/ha) } \\
\hline 2014 & 473,2 & 433,2 & 279,8 & 52,3 & 515,0 \\
\hline 2015 & 423,0 & 347,4 & 195,4 & 61,3 & 503,2 \\
\hline 2016 & 411,4 & 435,8 & 181,6 & 162,8 & 523,5 \\
\hline 2017 & 508,1 & 469,0 & 203,4 & 14,4 & 603,6 \\
\hline Change 2017-2014 & 34,9 & 35,8 & $-76,4$ & $-37,9$ & 88,6 \\
\hline \multicolumn{6}{|c|}{ Profitability of labour (thous. EUR/AWU) } \\
\hline 2014 & 5,2 & 13,2 & 10,1 & 2,2 & 11,2 \\
\hline 2015 & 4,8 & 10,7 & 7,1 & 2,6 & 11,2 \\
\hline 2016 & 4,7 & 13,3 & 6,6 & 7,0 & 12,0 \\
\hline 2017 & 6,0 & 14,0 & 7,7 & 0,6 & 13,9 \\
\hline Change 2017-2014 & 0,8 & 0,8 & $-2,4$ & $-1,6$ & 2,7 \\
\hline \multicolumn{6}{|c|}{ Return of assets (\%) } \\
\hline 2014 & 5,2 & 11,9 & 9,1 & 2,5 & 5,3 \\
\hline 2015 & 4,6 & 9,4 & 5,9 & 2,8 & 5,1 \\
\hline 2016 & 4,6 & 10,4 & 5,3 & 7,2 & 5,3 \\
\hline 2017 & 5,4 & 10,7 & 5,6 & 0,6 & 6,0 \\
\hline Change 2017-2014 & 0,2 & $-1,2$ & $-3,5$ & $-1,9$ & 0,7 \\
\hline
\end{tabular}

Source: authors' own study based on Eurostat data.

A similar dynamic of change was observed in the case of profitability of work, which in the Visegrad Group countries ranged from 2,200 EUR/AWU in 2014 in Slovakia up to 14,000 EUR/AWU in Hungary. It is worth noting that in the analysed group of countries the value of income per full-time employee was lower than the EU average in the analysed period, by over 50\% in the case of agricultural farms in Poland. The labour resources were used in Hungary most effectively, where the number of fulltime employees on the farm was the lowest. This may indicate a greater mechanization of activity compared to other countries.

Analysing the return on assets of the surveyed farms, it was found that it was most efficiently used in Hungary, where 100 EUR of assets generated between 9 EUR and 12 EUR of income, while the EU average was about 50\% lower and was 5-6 EUR. The lowest profitability of assets was recorded in Slovakia, where the indicator ranged from $2.5 \%$ in 2014 to $0.6 \%$ in 2017. Farms in Poland achieved a similar level of profitability to the EU average. In the analysed period, a decrease in the efficiency of the use of farm assets from V4 countries was observed, except for Poland, although this was not a uniform trend. When assessing the level of this indicator, it should be remembered that agriculture is a specific sector of the national economy characterized by quite low profitability of assets, which is mainly due to the large share in the balance sheet of fixed assets, whose turnover is slower compared to current assets. 


\section{Summary}

The efficiency of the use of production resources in agriculture depends on many factors, including area of agricultural land, human labour resources, the level of capital and its structure, external factors such as sales opportunities and prices of products, and natural conditions. The assessment of management rationality consists in determining the relation of the effects obtained, e.g. in the form of production value or income achieved, to the expenditure incurred. The objective of the study was to determine the efficiency of the use of land, labour and capital resources on farms of the Visegrad Group countries. Agriculture in the V4 countries with similar physical and geographical conditions pursues common agricultural policy goals.

Based on the analyses carried out, the following conclusions were formulated:

1. In the regions studied, there was a large variation in agrarian structure. The largest farms were in Slovakia and the Czech Republic, respectively over 500 and 200 ha of UAA, while the largest fragmentation was observed in Poland, where the average UAA in the studied period was 18.6 ha. The larger the UAA, the greater the number of employees, although the smaller the agrarian overpopulation (the number of full-time employees per 100 ha of UAA), the lower value of total assets per 1 ha of UAA.

2. In the years 2014-2017 the highest land productivity was recorded by Hungarian and Czech farms, while the lowest by farms in Slovakia, which proves that the efficiency of the use of land resources depends not only on the agricultural area at the farmer's disposal but also on its development and the rational use of other factors of production, i.e. labour and capital. It was also found that the greater the agrarian overpopulation, the lower the labour productivity. In addition, lower value of assets per 1 ha of UAA does not lead to deterioration of capital productivity on the surveyed farms, and even the reverse trend occurs. In the analysed period, an increase in land and labour productivity (with the exception of Poland), as well as a decrease in capital productivity was recorded, which is consistent with the general trend in the EU.

3. The highest profitability of land, with an upward trend, was recorded by farms in Poland and Hungary, although it was lower than the average in the EU. Farms in Slovakia were the worst in this respect, where in 2017 this indicator was over 35 times lower compared to Poland, which was due to the relatively low level of income achieved compared to the average UAA of farms.

4. In the analysed period, labour resources were most effectively used in Hungary, while the situation of farms in Slovakia was the worst in this respect, with the highest employment recorded. A similar trend was observed in the case of return on assets. In 2017, compared to 2014, farms in the Visegrad Group countries (except Poland) saw a decrease in the efficiency of the use of assets, which is a negative trend.

\section{Bibliography}

Barry P.J., Baker C.B., Ellinger P.N., Hopkin J.A., Financial Management in Agriculture. Interstate Publisher, Illinis 1995.

Bórawski P., Wielkość ekonomiczna jako czynnik różnicujący wyniki produkcyjne i ekonomiczne gospodarstw rolnych w regionie Pomorze i Mazury, Zeszyty Naukowe SGGW w Warszawie. Ekonomika I Organizacja Gospodarki Żywnościowej 67/2008.

Bud-Gusaim J., Efektywność zasobów produkcyjnych w rolnictwie indywidualnym Polski, PWN, Warszawa 1988.

Eurostat: https://ec.europa.eu/agriculture/rica/database/database_en.cfm (access: 18.11.2019).

Filipiak, T., Efficiency of production factors in horticultural holdings versus holdings of other agricultural types, Annals of the Polish Association of Agricultural and Agrobusiness Economists $21(4) / 2019$. 
Gałecka A., Efektywność gospodarstw rolnych w Polsce w latach 2012-2015 w zależności od ich wielkości ekonomicznej, Roczniki Naukowe SERiA, 19(5)/2017.

Gałecka, A., Typ rolniczy a efektywność gospodarstw rolniczych w Polsce, Zarządzanie Finansami i Rachunkowość 5(2)/2017.

Komorowska D., Typ rolniczy a efektywność gospodarstw ekologicznych, Roczniki Naukowe Rolnictwa i Rozwoju Obszarów Wiejskich 99(4)/2012.

Manteufel R., Ekonomika i organizacja gospodarstwa rolniczego, PWRiL, Warszawa 1979.

Marcysiak A., Efektywność wykorzystania zasobów produkcyjnych w różnych typach gospodarstw jako element oceny ich siły konkurencyjnej, Roczniki Naukowe SERIA, X(3)/2008.

Masternak-Janus A., Analiza efektywności gospodarowania przedsiębiorstw przemysłowych w Polsce, Economics and Management, 4/2013.

Niewiadomski K., Efektywność ekonomiczna gospodarstw rolniczych, Zagadnienia Ekonomiki Rolnej 3/2007.

Orłowska, M. J., Zasoby czynników produkcji oraz ich efektywność w gospodarstwach o różnej wielkości ekonomicznej w świetle FADN, Roczniki Naukowe Stowarzyszenia Ekonomistów Rolnictwa i Agrobiznesu 17(2)/2015.

Piwowar, A., Struktury rolne i produktywność rolnictwa w Grupie Wyszehradzkiej, Problems of World Agriculture, 17/2017.

Poczta W., Rolnictwo polskie w przededniu integracji z Unią Europejską, Wydawnictwo Akademii Rolniczej w Poznaniu, Poznań 2003.

Poczta, W., Średzińska, J., Wyniki produkcyjno-ekonomiczne i finansowe indywidualnych gospodarstw rolnych według ich wielkości ekonomicznej (na przykładzie regionu FADN Wielkopolska i Śląsk), Zeszyty Naukowe Szkoły Głównej Gospodarstwa Wiejskiego w Warszawie. Problemy Rolnictwa Światowego 2/2007.

Standard 2017 results obtained by agricultural holdings participating in the Polish FADN, Warszawa 2018

Szabo L., Grznar M., Zelina M., Agricultural performance in the V4 countries and its position in the European Union, Agricultural Economics, 64(8)/2018.

Szymańska E., Efektywność przedsiębiorstw- definiowanie i pomiar, Roczniki Nauk Rolniczych, SERIA G 97(2)/2010.

Wasilewski M., Wasilewska A., Koszty i efektywność pracy w przedsiębiorstwach rolniczych, Roczniki Nauk Rolniczych, Seria G 94(1)/2007.

Zegar J.S., Dochody rolników po akcesji w Unii Europejskiej, Raport „Realia i co dalej” 4/2011.

Ziętara W., Zieliński M., Efektywność i konkurencyjność polskich gospodarstw rolniczych nastawionych na produkcję roślinną, Zagadnienia Ekonomiki Rolnej 1/2012.

\section{Efektywność wykorzystania czynników produkcji w gospodarstwach rolniczych państw grupy wyszehradzkiej}

\section{Streszczenie}

Celem opracowania było określenie efektywności wykorzystania czynników produkcji w gospodarstwach rolniczych państw Grupy Wyszehradzkiej. Badaniami objęte zostały gospodarstwa uczestniczące $\mathrm{w}$ europejskim systemie zbierania danych rachunkowych Z gospodarstw rolnych FADN (Farm Accountancy Data Network). W ramach celu głównego dokonano oceny produktywności i dochodowości ziemi, pracy i kapitału. Okres badawczy obejmował lata 2014-2017.

Na podstawie przeprowadzonych analiz stwierdzono, że najefektywniej zasoby ziemi były wykorzystywane na Węgrzech i w Polsce, zaś najmniej efektywnie na Słowacji. Biorąc pod uwage produktywność pracy i kapitału najwyższe wyniki osiągnęły gospodarstwa z Czech i Słowacji, zaś 
najniższe gospodarstwa polskie. Natomiast najwyższą dochodowością pracy i majątku charakteryzowały się gospodarstw węgierskie, gdzie analizowane wskaźniki były wyższe od średniej w UE.

Słowa kluczowe: efektywność, gospodarstwa rolne, FADN, grupa Wyszehradzka JEL Codes: Q12, Q14

\section{Information about authors:}

Agnieszka Gałecka, PhD

John Paul II State School of Higher Education in Biała Podlaska

Sidorska St. 95/97, 21-500 Biała Podlaska, Poland

e-mail: a.galecka@dydaktyka.pswbp.pl

ORCID: 0000-0002-7603-8086

\section{Agnieszka Cyburt, PhD}

John Paul II State School of Higher Education in Biała Podlaska

Sidorska St. 95/97, 21-500 Biała Podlaska, Poland

e-mail: a.cyburt@dydaktyka.pswbp.pl

ORCID: 0000-0002-7084-6066 